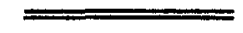

\title{
ANNUAL
}

\section{CONFERENCE 1973}

will be held at the

University of Sussex, Brighton

Starting mid-day on Tuesday 10 April

Ending mid-day on Thursday 12 April

Residential Accommodation will be available on the campus.

Leaflets giving full details will reach members before the end of the year. 


\title{
EDUCATIONAL STUDIES IN MATHEMATICS
}

Editor: H. Freudenthal, Mathematical Institute, University of Utrecht, The Netherlands Editorial Board: D. K. Abbiw-Jackson, Kumasi; E. G. Begle, Stanford; Mlle E. Castelnuovo, Rome; G. Choquet, Paris; A. Engel, Stuttgart; Mme L. Félix, Paris; H. B. Griffths, Southampton; P. Hilton, Seattle; C. Hope, Worcester; Mme A. Z. Krygovska, Cracow; W. T. Martin, Cambridge; H. $O$. Pollak, Murray Hill; A. Revuz, Paris; W. Servais, Morlanwelz: S. Sobolev, Novosibirsk; H.-G. Steiner, Bayreuth; P. Suppes, Stanford: B. Thwaites, London.

Contents of Volume 4, No. 3

A. Revuz / La notion de continuité dans l'enseignement du second degrt. Compte rendu d'une experience. - K. E. Hirst / Derivatives and Tangents. - Max Jerman and Raymond Rees / Predicting the Relative Difficulty of Verbal Arithmetic Problems. - Philip S. Marcus / Comments on Variable-Free Calculus. - Joseph M. Scandura and Robert McGee / An Exploratory Investigation of Basic Mathematical Abilities of Kindergarten Children. - T. Varga / Logic and Probability in the Lower Grades. Hugh Thurston / What Exactly is dy/dx? - Josette Adda / Quelques études pour contribuer à l'observation du comportement mathématique des non-mathématiciens. - A. F. Monna / Set-Theory in 1888. XIIIth International Olympiad Bratislava-Zilina, 7-20 July, 1971.

Subscription price per volume of four issues Dfl. 100,- (US \$32.00) including postage. One volume is published yearly. Personal subscription price on reauest.

\section{REIDEL PUBLISHING COMPANY}

\author{
P.O. BOX 17 - DORDRECHT-HOLLAND
}

\section{Linear Programming}

\section{KATHLEEN TRUSTRUM University of Sussex}

This book provides a balance between the theory and application of linear programming and is suitable for any student who is familiar with matrix algebra. The first chapter develops the mathematical tools, which are then used in the second chapter to determine the properties of the optimal solution and the conditions under which it exists. In chapter three, a method for solving the transportation problem is given and the simplex method, which can be used to solve any linear programme, is described in chapter four. Finally, the relationship between linear programming and matrix games is established in chapter five.

\section{Library of Mathematics cloth 80p paper 40p Routledge 68 Carter Lane, London EC4V 5EL}




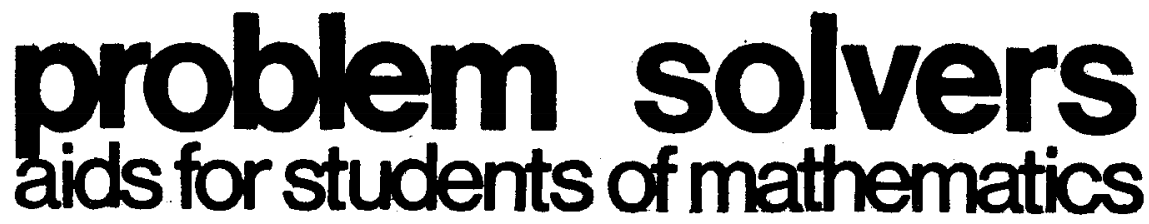

The student's aids to working and solving problems-

\section{Analytical Mechanics \\ D. F. Lawden}

With this work the student can determine the behaviour of a wide variety of mechanical systems, moving in two or three dimensions.

E1.90: paper $£ 0.80$ IIlustrated

\section{Complex Numbers}

\section{J. Williams}

Covers all the essential manipulations up to and including simple mapping.

El.90: paper 60.80 Illustrated

\section{Matrices and Vector Spaces}

\section{F. Brickell}

Matrices, determinants and the theory of vector spaces are clarified in this volume.

E1.75: paper $€ 0.80$

\section{-Problem Solvers}

\section{George Allen \& Unutin PARK LANE, HEMEL HEMPSTEAD, HERTS}




\section{New from Oliver \& Boyd ...}

\section{Introduction to Graph Theory}

R. J. WILSON

Graph theory is rapidly emerging as a subject in its own right, as well as being an important mathematical tool in such diverse subjects as operational research, chemistry, sociology, genetics etc.

Robin Wilson's Introduction to Graph Theory provides an inexpensive text for the student, specifically aimed at the undergraduate and graduate courses which are being started in many mathematics departments. It is also an eminently readable book for the non-mathematician wishing to learn the subject as quickly as possible.

$£ 1.50$ paperback

\section{Advanced Calculus I}

\section{R. P. GILLESPIE}

The latest addition to the popular series 'Solving Problems in Mathematics' gives a thorough coverage of the standard course in advanced calculus for first degree students in pure mathematics, physics and engineering. Dr Gillespie emphasises those problems which involve physical application and in this text maintains the high standards which are associated with his work.

$£ 1.50$ paperback 


\section{Introduction to Metric Spaces}

\section{G. C. PITTS}

The gieat importance of functional analysis has been realised since the 1930's; however, it is only recently that the subject has formed any important part of undergraduate mathematics courses. Metric spaces, as the simplest mathematical system to be studied is a necessary introductory topic. Until this publication metric spaces had largely been treated in graduate level text books. This text presents a full and clear discussion of the subject, aimed at the 2nd and 3rd year level undergraduate, in a compact and readable form.

\section{$£ 1.50$ paperback}

\section{Elementary Rings and Modules}

\section{IAIN T. ADAMSON}

The study of modules over an arbitrary ring is a natural follow-up to an introductory course in linear algebra. This book is intended to provide the basic material for such a study; it is essentially self-contained since it includes a quick introduction to the elementary ideas of abstract algebra.

$£ 1.50$ paperback

\section{Otiver \& Boyd}

Tweeddale Court,

14 High Street, Edinburgh EH1 1YL

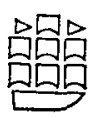




\section{modern}

\section{mathematics}

for schools

\section{The Scottish Mathematics Group SECOND EDITION}

Catering for a wider range of ability than before$A$ and $B$ sets of exercises have been introduced and the pace of the earlier books has been slowed down.

Methodical consolidation and revision built in at every stage.

Computer studies introduced from Book Four onwards.

Progress Papers (plus Pupils' Answer Sheets and Teachers' Answer Keys), facilitating continuous assessment of understanding and achievement.

A new set of Sixth Year books to bridge the gap between school and university.

A leaflet detailing the special features of this new edition and the stage reached in its publication is being sent to Mathematics Departments of UK Secondary schools this autumn.

\section{Blackie}

Bishopbriggs, Glasgow

\section{Chambers}

II Thistle Street, Edinburgh EH2 IDG 
computing in schools?

An introductory course for average young pupils was what the British Computer Society's Schools Committee recommended (and so, in Scotland, did an SED report)*

But you didn't have the material .....

Now you do-at both Primary and Secondary level

Computers and Young Children

A guide for Primary teachers, containing many detailed suggestions for work with children, which covers flow charts, punched cards and games in which children perform the functions of the computer. It also describes work done in a few schools with an actual computer. It is intended, not for use as a concentrated course, but to provide activities which may be integrated, over a long period, with other subjects.

A Nuffield Mathematics Project Teachers' Guide, published jointly with John Murray

0550770232 (Chambers)

071952653 I (Murray) \&l.20

\section{The Computer: Yours Obediently} The Scottish Computers in Schools Project

An introductory activity course for Secondary pupils-and their teachers-this was specifically designed to fulfil the recommendations of the official reports.

It comprises pupils' books, pupils' workbooks, teachers' books and colour slides. Alone the teachers' books provide a background to computer studies: together with the pupils' material they form an introductory activity course.

And you don't have to be a mathematician to use it: it has been compiled for use by teachers of any discipline. Try it with your pupils of 13 and upwards.

A 12-page descriptive leaflet and inspection material are available from the publishers.

Part One Understanding the Computer Already published

Part Two Applications Projects Mid-1973

Part Three Various Options in Programming In preparation

\section{Chambers}

11 Thistle Street, Edinburgh EH2 IDG

- 'Computer Education for All' (The British Computer Society's Schools Committee) and 'Computers and the Schools' (The Scottish Education Department) 


\title{
Oxford Middle School Mathematics
}

\author{
D. PALING, J. E. HISCOCKS, \\ and W. E. NICKELS
}

This course caters in particular for Middle Schools. Junior and secondary schools will also find the series of great help, as it attempts to bridge the mathematical gap which sometimes occurs.

The content is modern and is planned so that mathematical ideas are carefully developed. The approach used is interesting and lively and is directed towards the children being given opportunities to think and find out for themselves. The series is fully metricated, and provides an excellent preparation for the mathematical work which follows at later stages.

\section{The Pupils' Books}

The four books are well illustrated, clearly laid out, and have an open format. Colour is used to bring out significant mathematical points, as well as to provide an attractive page. Particular care has been taken to ensure that the language used is appropriate at each stage.

\section{The Teacher's Books}

For each page in the children's books, help is provided under the headings Aim; Introductory Activities; Using the page (including answers); Further Activities. Where appropriate the background ideas are discussed, and their relevance to the work as a whole is indicated, while charts show the teacher how his work fits into the total scheme.

\section{The Workbooks}

Each workbook contains a series of worksheets related directly to pages in the Pupils' Book. Their use reduces the amount of preparation required for the activities, and helps pupils to concentrate their efforts on the mathematical ideas involved.

A detailed prospectus is available on application to

\section{OXFORD UNIVERSITY PRESS Education Department, Oxford}

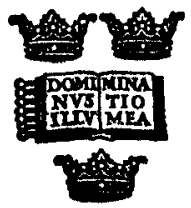




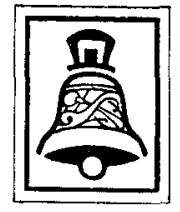

\section{BELL}

\section{METRICATED EDITIONS FROM BELL}

Elementary Analysis

A. DAKIN and R. I. PORTER

Further Elementary Analysis

R. I. PORTER

Further Mathematics

R. 1. PORTER

A School Course in Vectors

R. I. PORTER 3rd Edition 390 pages $87 \frac{1}{2} p$

4th Edition 382 pages $£ 1.40$

2nd Edition 424 pages $\quad$ fl.45

Vectors and their Application to Geometry and Mechanics
A. J. FRANCIS
2nd Edition 148 pages $\quad 72 \frac{1}{2} p$

Mechanics

P. GANT

3rd Edition 224 pages $\quad$ El.20

\section{Elementary Mechanics}

D. A. QUADLING and A. R. D. RAMSAY 2nd Edition

Volume I 300 pages $\boldsymbol{E} \mathbf{1 . 4 0}$

Volume 2376 pages $\mathbf{E I . 8 0}$

\section{Certificate Mathematics}
C. V. DURELL
2nd Edition
Volume I 288 pages
Volume 2290 pages
Volume 3240 pages
El.IO (With answers $€ I . I 2 \frac{1}{2}$ )
$E I .10$ (With answers $E I .12 \frac{1}{2}$ )
Volume 4256 pages
EI.20
EI.20
(With answers $E I .25$ )
(With answers $\mathrm{EI} .25$ )

School Mathematics

H. E. PARR

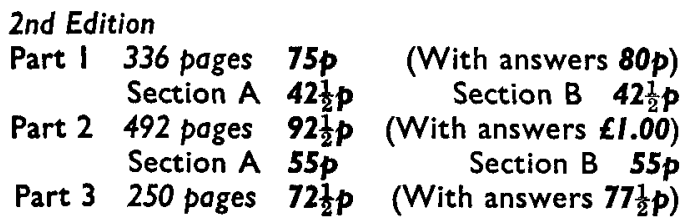

Revision Course in School Mathematics

H. E. PARR

2nd Edition $2 / 4$ pages $97 \frac{1}{2} \mathrm{p}$

\section{Modern Mathematics}

H. E. PARR and J. R. SHELLEY

2nd Edition

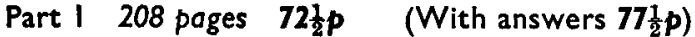

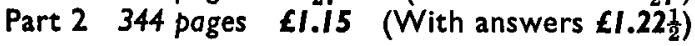




\title{
MATHEMATICS:
}

\section{THE CHANGING SCENE ...}

\section{A conference for teachers of mathematics}

\author{
University of Southampton \\ 3rd-5th January, 1973
}

The past few years have seen a very substantial growth and change at many levels in the teaching and use of mathematics. This conference has been designed to give the teachers, particularly teachers of VIth form mathematics, an appreciation of this changing scene through talks and group activities. There will be a session on careers and the conference will conclude with an open forum. Speakers include:

Professor H. Bondi, F.R.S. $\quad$ Dr. T. J. Fletcher, H.M.I.

Professor H. B. Griffiths

Professor J. W. Craggs

Professor P. T. Landsberg.

Closing date for applications: 20th November, 1972.

For further details, contact:

Conference Secretary,

Department of Mathematics,

University of Southampton,

Southampton, SO9 5NH. 


\section{THE MATHEMATICAL ASSOCTATION}

The fundamental aim of the Mathematical Association is to promote good methods of mathematical teaching. Each member receives four issues of the Mathematical Gazette and/or six issues of Mathematics in School (according to the class of membership chosen), together with any Newsletters and Reports published during the year. Intending members should ask the Executive Secretary for information and application forms.

The address of the Association and of the Hon. Treasurer and Secretaries is 150 Friar Street, Reading RGl 1HE. Telephone Reading 581389.

Change of address should be notified to the Membership Secretary at the Reading office. If copies of the Association's periodicals fail to reach a member for lack of such notification, duplicate copies can be supplied only at the published price. If change of address is the result of a change of appointment, the Membership Secretery will be glad to be informed.

Subscriptions should be paid to the Hon. Treasurer.

The Library is housed in the University Library, Leicester.

Correspondence for the Problem Bureau should be addressed to $\mathrm{Mr}$. R. H. Cobb, 9 The Lees, Malvern, Worcs.

\section{Editor:}

\section{THE MATHEMATICAL GAZETTE}

Mr. D. A. Quadling, 12 Archway Court, Barton Road, Cambridge CB3 9LW.

\section{Assistant Editors :}

Dr. J. Howlett, Atlas Computer Laboratory, Chilton, Berks.

Dr. F. Rhodes, Department of Mathematics, The University, Southampton SO9 $5 \mathrm{NH}$.

Mr. J. Hersee, 76 Pembroke Road, Bristol BS8 3EG.

Material for publication, and books for review, should be sent to $\mathrm{Mr}$. Quadling. Authors will be notified as soon as possible whether or not their contributions can be accepted; if an immediate acknowledgment is required, they should send an addressed, reply-paid postcard with their contribution.

Each assistant editor will be concerned with a particular aspect of the contents of the Gazette: Dr. Howlett with applied mathematics, Dr. Rhodes with pure mathematics and Mr. Hersee with mathematics at school level.

Business and advertising correspondence should be addressed to the Executive Secretary at the Reading office of the Association. 


\section{CONTENTS}

$\begin{array}{lll}\text { Whatever Next. } & \text { B. T. Bellis } & 179\end{array}$

Early Warning. Graham S. Smithers 188

Can Regular Tetrahedra be Glued Together Face to Face to form a Ring? J. H. Mason

A Nonrelativistic Analogy to Relativistic Time Dilatation. John E. Prussing

The Fundamental Formula in the Algebra of Sets.

R. L. Goodstein"

The Transition from School to University Mathematics.

M. L. Cornelius

Classroom Notes

Mathematical Notes

Correspondence

Reviews 